\title{
Inculturação litúrgica: Sacramentais, religiosidade e catequese
}

\author{
Anscar J. Chupungco \\ São Paulo : Paulinas, 2008. 191p.
}

A obra se divide em quatro capítulos que funcionam como partes de um estudo extremamente competente e caprichoso: questões preliminares da inculturação; sacramentais e inculturação litúrgica; religiosidade popular e inculturação; a inculturação da catequese litúrgica. Diga-se de passagem que Anscar J. Chupungco é profundamente envolvido com a ciência litúrgica, elemento que já traz na sua matriz monática. Mas foram os longos anos de magistério, pesquisas e debates no Pontifício Instituto Sant'Anselmo, Roma, que Ihe deram o estofo para escrever uma obra como esta. Atualmente,é também diretor do Instituto Paulo VI de Liturgia, nas Filipinas.

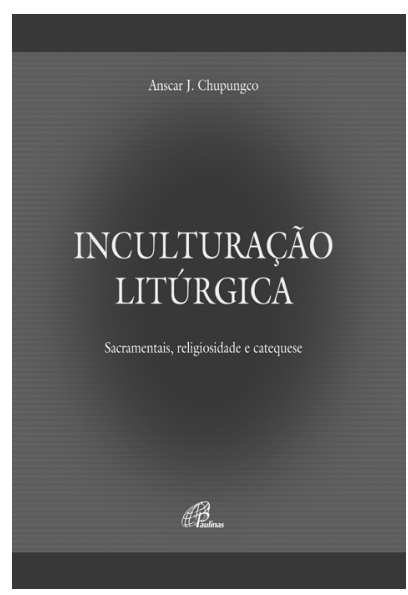

A obra Inculturação litúrgica: Sacramentais, religiosidade e catequese apresenta, no seu início, uma série de questões preliminares sobre a inculturação para depois partir para sugestões concretas a respeito da possibilidade da inculturação nos sacramentais, na religiosidade popular e catequese

$\mathrm{O}$ autor vai delineando o processo que levou à adoção do termo inculturação. Parte da definição dos termos, começando por indigenização, termo que surgiu na década de 70 , depois do termo encarnação do Decreto Ad Gentes, do Concílio Vaticano II. Depois vem o termo contextualização que foi introduzido pelo Conselho Mundial das Igrejas em 1972. Baseados na Constituição litúrgica Sacrosanctum Concilium, do Concílio Vaticano II, aparecem os termos revisão e adaptação. Por fim, o termo inculturação que foi criado em 1973 por G.L.Barney, um missionário protestante e professor na Nyack Alliance School of Teology, em Nyacd, Nova York. Este fervilhar ocorreu na mesma década da revisão dos livros litúrgicos, em vista da reforma do Concílio. Desta forma, os liturgistas estavam muito ocupados 
com esta tarefa concreta e, somente, em 1979, C. Valenziano, professor de antropologia cultural no Pontifício Instituto Litúrgico Sant'Anselmo em Roma, emprega o termo pela primeira vez.

Para aprofundar o que é inculturação, o autor trabalha o termo aculturação e, depois, inculturação litúrgica. A partir daí, define o que seria um processo de inculturação, onde se tem de levar em conta o padrão cultural de cada povo, para se criar métodos de inculturação entre os quais são nomeados o método da equivalência dinâmica, o método da assimilação criativa e o método da progressão orgânica. Evidentemente esses métodos, com suas características, apontam para o rumo da criatividade litúrgica.

Daí em frente, se pode perceber que o autor encoraja o leitor a assumir a inculturação como um elemento litúrgico de relevância e, para tanto, é necessário realizar uma consistente criatividade litúrgica, como o rito romano fez na sua origem.

Com esta base vai-se trabalhando o que seria uma criatividade litúrgica nos sacramentais da Igreja, levando em consideração a abertura que o Concílio mesmo ofereceu, de onde se podem extrair os princípios teológicos, culturais e pastorais. Antes, é preciso saber o que realmente são os sacramentais na dinâmica da sacramentalidade da liturgia da Igreja.

Na sequência, o autor faz o mesmo trabalho em relação à religiosidade popular, buscando defini-la e, ao mesmo tempo, apontando para o ponto de intersecção com a liturgia. Nesta altura, lembra que estudos do textos litúrgicos da Oração Coleta da Missa do Tempo do Natal, qui humanae sustantiae dignitatem, abribuida a Leão I, mostram traços nítidos de uma inculturação no contexto do afrontamento com os maniqueus.

Por fim, o autor trata da catequese litúrgica, a partir dos seus fundamentos patrísticos. Lembra que para os catequistas, João Paulo II, na exortação apostólica Catechesi Tradendae, ordena que conheçam, valorizem e respeitem a cultura específica em que trabalham.

Depois de mais de quarenta anos de aplicação da reforma litúrgica, corre-se o risco de se cair num novo rigidismo litúrgico por causa de experiências de criatividades fracassadas, por falta de um lado de conhecimento da natureza da liturgia e, por outro, de respeito ao padrão cultural de cada comunidade. 
Uma obra como esta ajuda a levar a sério a questão da inculturação que foi a experiência forte do rito romano nascente, alertando para o aspecto teológico-científico que a discussão precisa tomar. E, pelo que consta, Chupungco é o único autor a abordar neste nível um tema tão urgente e tão espinhoso. Deve atrair portanto, os leitores interessados em enfrentar o desafio sempre presente da inculturação litúrgica.

Como o próprio autor admite, restam lacunas que é preciso se preencher e indagações que só a pesquisa e a prática concreta podem responder. A inculturação nos sacramentais pelo viés da religiosidade popular é, de certa forma, um golpe de mestre, pois há um enorme campo à espera, o que já seria mais complicado com os sacramentos em geral. Esta lacuna continua existindo em nossa reflexão teológico-litúrgica.

A partir da obra em questão, podemos concluir sem medo de errar que, assim como se costumou chamar de participação ativa qualquer tipo de participação que levasse a destaques durante a celebração litúrgica, assim também foi chamada de inculturação qualquer tipo de criatividade que se fazia em nossas celebrações. Daí, passados mais de quarenta anos da Sacrosanctum Concilium, paira uma forte sensação de que há, por um lado, um "freio" por parte da autoridade litúrgica preocupada com experiências negativas, e uma insegurança por parte dos que praticam a liturgia, por falta de maior conhecimento da ciência litúrgica. É preciso avançar com consciência, isto é, com a potencialidade da ciência da liturgia, levando sempre em consideração a realidade cultural e suas tradições litúrgicas, a Tradição da Igreja e os desafios do momento presente.

Prof. Dr. Pe. Valeriano dos Santos Costa Professor de Liturgia da Faculdade de Teologia Nossa Senhora da Assunção - PUC-SP 